\title{
Determinants of Tax Non-Compliance among Small and Medium Enterprises in Zimbabwe
}

\author{
Banele Dlamini \\ Department of Accounting and Finance, Lupane State University, Zimbabwe \\ bdlamini@lsu.ac.zw; dlabukhosi@gmail.com
}

\begin{abstract}
Small and medium-scale enterprises (SMEs) are recognized global for being the backbone of the economy through; economic advancement; innovation, wealth generation and furthering growth. SMEs have a high tax non compliance rate which hinders the development they bring to many economies. This paper aims to establish the major determinants of tax non-compliance among SMEs in the Zimbabwean economy. The survey research design was used and the SMEs operating in the Bulawayo provincewere considered as the sample of the study. The stratified random sampling technique was adopted in eliciting information and questionnaires were administered in the collection of data from the respondents. 187 questionnaires were issued out and 150 were returned. Regression analysis was used to establish the relationship that exists between tax non-compliance and the predictive variables, using SPSS ver. 22. The study revealed that poor follow-up strategy and lack of a tax audit, high tax rates, financial constraints, abuse of public funds by authorities and tax education as the major determinants. SME operators should apply modern business survival strategies so as to counter financial constraints. ZIMRA should maintain a database for SMEs for tax audit purposes; intensify follow-up strategies, increase tax audits and increase tax support services to SMEs. The government should consider reducing tax rates (which are perceived to be too high) as they promote tax evasion and failure among SMEs.
\end{abstract}

Keywords: Tax compliance, tax evasion, Small and Medium Enterprises, economic development and Zimbabwe

\section{Introduction}

Globally, tax compliance among Small and Medium Enterprises (SMEs) is poor and a major problem as many countries fail to come up with ways to cut non-compliance. Small and Medium Enterprises (SMEs) are now the major employers and they play a very vital role in the development and growth of the Zimbabwean economy, but their contribution to the national budget is affected by tax non-compliance exercised by the operators. A study carried out by the Fin mark Trust revealed that Zimbabwe has 3.5 million Small to Medium Enterprises with only $2 \%$ of all these paying taxes to Zimbabwe Revenue Authority (ZIMRA; Masarirambi, 2013; CZI, 2015). A number of ways and strategies to cut tax evasion have been devised by ZIMRA as the government revenue collecting board to cut non-compliance among SMEs. SMEs is subjected to tax incentives as long as they are registered with ZIMRA, they are eligible to enjoy 100\% Special Initial Allowance (SIA) on qualifying capital assets, which is allowed over a four-year period at the rate of $25 \%$ per year (www.zimra.co.zw). The Special Initial Allowance is a capital allowance ranked as a deduction, which reduces the tax due from the business since it has the benefit of reducing the taxable amount. The incentive enables re-investment which empowers growth through more of its earnings that have been retained for business. Workshops are conducted by ZIMRA on tax education. Are these methods conducted by ZIMRA real incentives for tax compliance? ZIMRA introduced a penalty of $100 \%$ of the amount due plus $10 \%$ interest per year to taxpayers who fail to file their tax returns in the stipulated time (Tapera, 2013). Heavy penalties have been charged with the authority to SMEs which fail to comply with the regulations on tax remittances. ZIMRA seem to be applying both persuasion and coercion strategies for tax compliance, relying more heavily on the semi-military operations which give results in the short run, but proving to be difficult to sustain in the prevention of tax evasion. The SMEs contributes a small amount of tax as compared to larger companies; they still need to be carefully considered due to the contribution they bring to the economic growth. The question then is why do other SMEs comply whilst the majority is not remitted their taxes? What are the major determinants of the failure to comply with the regulations of the tax authority?

The government uses tax revenue as the major source for capital and infrastructural development projects that will be of benefit even to the SMEs. The findings and recommendations of the study will help ZIMRA in the formulation of policies on collection of taxes among SMEs. Tax revenue contributes more than $60 \%$ of the national budget (Ministry of Finance 2013 and 2014). Reducing non-tax compliance among SMEs will fabricate an environment that eases the running of their businesses in the long run through infrastructural 
development and economic growth. The study is significant because taxation is the pivot to economic, political and social development. The strong tax system plays three major roles in economic development; stimulate good governance (Odd-Helge \& Rakner, 2009), lessen inequality (Cobham, 2005) and generates revenue (Keen, 2012). There is little evidence of research knowledge on the SMEs and tax noncompliance in Zimbabwe, previous studies focused on tax compliance challenges in fulfilling tax obligations among SMEs in Zimbabwe (Zivanai, Chari, Nyakurimwa, 2016). Utaumire, Mashiri, and Mazhindu (2013) conducted a study on the effectiveness of the presumptive tax system in Zimbabwe using ZIMRA as a case study; they did not consider the factors which cause tax evasion by SMEs. The study will also provide invaluable insights to the Government of Zimbabwe in the formulation of future tax policies and address the major contributing factors of tax noncompliance among SMEs. The government has to know and attend to the reasons why SMEs are invading taxes as they form the core of the majority of the country's economy. This paper is organized as follows; it gives the aims of the study and briefly defines SMEs in the context of Zimbabwe and reviews theoretical and empirical literature from earlier studies. Then method on the data collected in the study will be analysed to show the factors which cause tax evasion among SMEs in Zimbabwe. The conclusion will be made based on the findings of the study and recommendation of the major determinants of tax noncompliance among Small and Medium Enterprises in Zimbabwe.

\section{Objectives of the study}

- To identify the major causes of tax non-compliance among SMEs in Zimbabwe.

- To recommend possible ways of reducing tax non-compliance among SMEs in Zimbabwe.

\section{Literature Review}

Definition of SMEs: There are many definitions that have been brought forth by different authors, boards, and countries; the study will consider the definition applied in Zimbabwe. According to Small and medium enterprises act, chapter 24:11, an SME is a corporation or an unincorporated business entity which is managed by a person or jointly by more persons and it should either be a micro- enterprise or small enterprise or medium-sized enterprise. The SME Association of Zimbabwe defines in different categories as follows; a business with a turnover of less than US $\$ 240000$ or assets less than US $\$ 100000$ should be formally registered as a small business and a business with assets and turnover above the thresholds stipulated for small enterprises, but less than US $\$ 1$ million each should be registered as a medium enterprise (www.smeaz.org.zw). ZIMRA defines SMEs as follows: a business with six (6) to forty (40) employees, annual turnover of US $\$ 50000$ to US\$500 000 and assets valued between US\$50 000 to US\$1 million is treated as a small company, a business with forty-one (41) to seventy-five (75) employees, annual turnover, and assets between $\$ 1$ million and US $\$ 2$ million should be registered as a medium-sized company. A microenterprise is a business that operates below the threshold of a small enterprise (www.zimra.co.zw). All business entities in Zimbabwe are expected to remit taxes, according to their tax liability and SMEs also have a tax obligation.

Tax Obligations: Tax Obligations is the amount of tax due according to the current tax law. The Zimbabwe Revenue Authority (ZIMRA), as a body responsible for collecting revenue for the country through taxes, get its commission from the Revenue Authority Act [Chapter 23:11], which was passed by the parliament of Zimbabwe in 2002 and other related legislation. There are a number of taxes that operating SMEs in Zimbabwe are expected to remit, they may be obligated to any or all the following: Income Tax, Value Added Tax (VAT), Presumptive Tax, Capital gains tax, Pay As You Earn (PAYE), Estate duty tax, Withholding Tax (WHT), Investment income tax, among others (www.zimra.co.zw). Small traders who are not qualifying for income tax remittance should pay a tax referred to as a Presumptive tax. Those that register for income tax purposes with ZIMRA are expected to submit returns and payment of taxes according to the statutory requirements. The rate of tax on taxable income is 25\% plus 3\% Aids Levy (Tapera, 2013). Utaumire, et al (2013) stated that SMEs are willing to pay their tax obligations, which was contrary to the findings of a study conducted by Devos, (2014) who said tax payers try by all means to evade taxes; the tax authority should come up with strategies to counteract tax evasion.

Strategies to counteract tax evasion: ZIMRA introduced tax audits to reduce tax non-compliance and a penalty as a control aimed to reduce or discourage taxpayers from evading tax, a penalty of $100 \%$ of the amount due and a 10\% interest is also used by ZIMRA (ICAZ, 2013). ZIMRA educate taxpayers through 
holding forums, workshops, and seminars educating the public on how to improve on tax compliance (www.zimra.co.zw; ICAZ, 2013). There is a toll-free line for taxpayers to seek clarity anytime on tax issues (www.zimra.co.zw). Reduction in the loss of revenue through the use of electronic devices in VAT collection and these devices are not to be tampered with. Small and medium businesses are encouraged to adopt Generally Accepted Accounting Practice (GAAP) in accounting so as to cut incidences of cheating on transactions. Whistle blowing, road patrols on the ZIMRA website and the dismissal of corrupt employees are other measures in place (AFRODAD, 2011). According to Mello, (2008) different strategies to cut tax noncompliance has been introduced in different countries such as tax audits, tax education workshops, tax farming, General Anti-avoidance Rule and many others. Amnesty to taxpayers who have defaulted was granted by South Africa to bring them back into the tax net. It was not successful with the small and medium sized businesses, but a success with larger taxpayers (www.afrodad.org). Zimbabwe granted a six months tax amnesty in October 2014 to March 2015, so as to aid taxpayers in regularizing their business affairs, but very few businesses came up front to apply for the amnesty. In order to come up with good strategies for tax evasion, tax compliance models have been developed by various scholars.

\section{Tax compliance models}

The A-S model: The A-S model is a formal economic analysis of tax evasion also known as the Deterrence model or Classical Approach; it was pioneered by Allingham and Sandro (1972), taxpayers who are assumed to be rational and moral making reasonable economical real decisions. Evading tax is grounded on perceived gains or losses (Gahramanov, 2009); if the gain expected by evading taxes is higher than the cost involved they evade taxes (Fischer et al. 1992; Devos, 2014). The taxpayers are assumed to have real knowledge of tax, penalty and detection rates as utility maximizers (Devos, 2014). The model state that at the moment of computing tax returns, the taxpayer is inclined to evade tax to maximize profits (Zivanai, et.al. 2016). The questions they have are; how much income should I report and how much tax should I evade? If the tax authority has a sound system and the likelihood of being caught is high and the penalties are inevitable, a rational economic decision maker will correctly remit taxes (Bătrâncea, 2012). When there is no tax audits performed and poor collection systems, taxpayers can remit less tax than what is expected. This implies that few taxpayers will evade taxes if detection is certain and penalties are severe (Ali, et.al. 2013). The model has been subject to harsh critics, as it assumes that taxpayers are fully rational utility maximizers; empirical studies show that many people are honest taxpayers and other taxpayers have never evaded taxes (Gordon, 1989; Erard \& Feinstein, 1994; Andreoni, Erard \& Feinstein, 1998). Yitzhaki (1974), suggested solutions to the shortcomings of the A-S model of tax evasion by setting a penalty on the amount of tax evaded and not on the undeclared income (Bătrâncea, et.al., 2012) suggesting the use of the slippery slope model.

Slippery slope model: The slippery slope approach assumes two major views to tax compliance is a hindrance of tax evasion by the performance of tax audits and severe fines and on the other hand cultivating a trusting relationship between the taxpayers and tax authorities (Kirchler, 2007; Kirchler, Hoelzl, and Wahl, 2008). The model suggests that the trust in the tax authorities and power of tax authorities is both key dimensions in tax compliance both enforced and voluntary compliance. Power is related strongly to antagonistic climate and trust relates strongly to synergistic climate. Power is characterized by view where taxpayers are perceived as "robbers" looking for an opportunity to evade tax. This is the scenario in the informal sector in Zimbabwe (Zivanai, et al, 2014). Trust cause, voluntary tax compliance as taxpayers willingly returns their taxes as they perceive the authorities as a philanthropist in the society (Kirchler, 2007; Kirchler et al., 2008). According to the framework maximum level of tax compliance is achieved in the conditions of high power and or high trust, though the derived compliance, quality will differ whilst distrust and resistance is a result of a 'cops and robbers' climate which breeds cheating behavior (Bătrâncea, et.al. 2012). According to Tayler (2006); Kirchleret al. (2008); Fauvelle-Aymar (1999) the extent of trust the citizens have with their government influences their tax compliance; if they do not trust the government they will evade taxes. 
Figure 1: The Slippery Slope Framework (Kirchler et al., 2008)

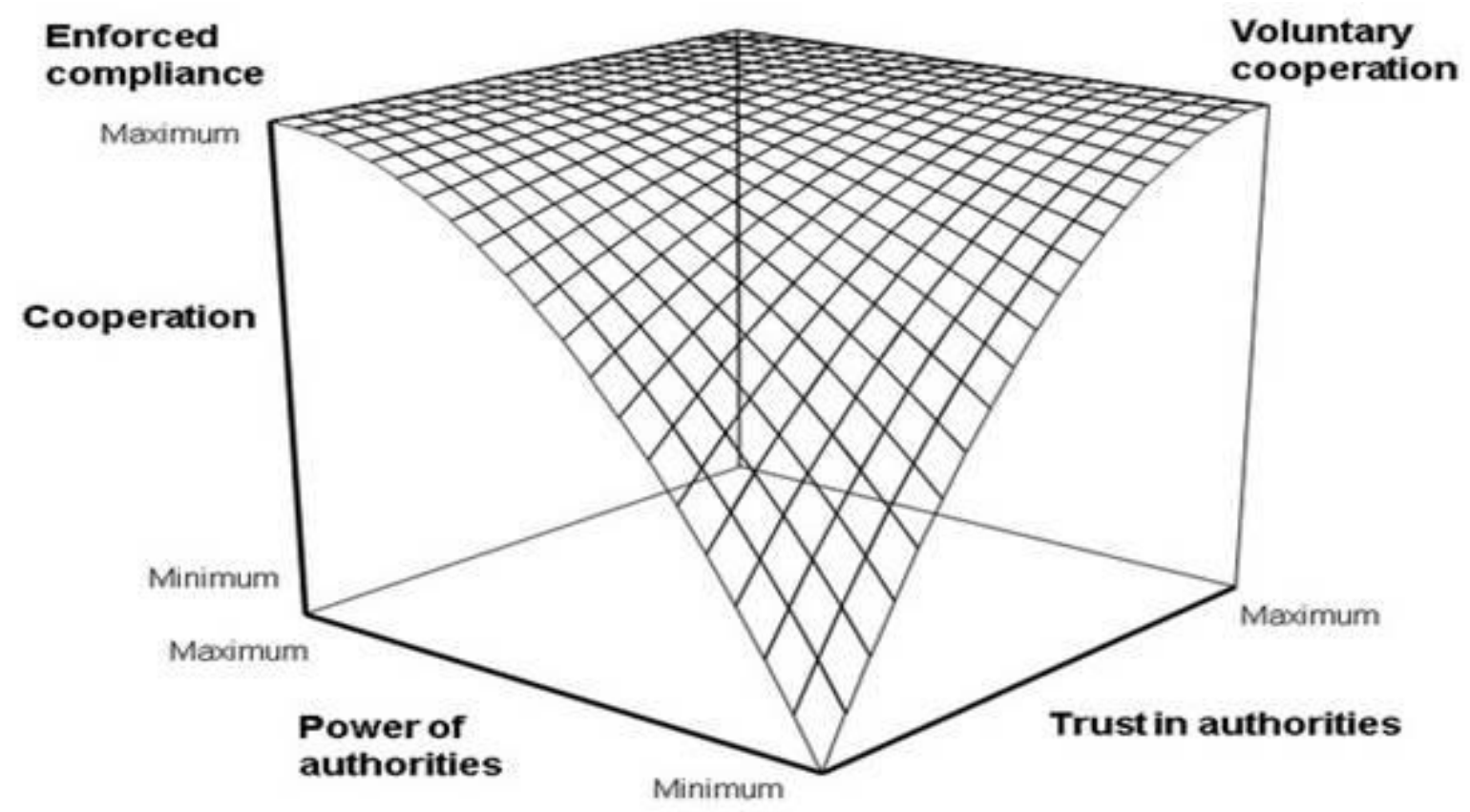

Fiscal and Social Psychology Models: The model blends economic deterrence aspects and social psychological aspects. Social psychology models focus on variables such as moral values and the perception of fairness of the tax system and the tax authorities. The behavior and attitude of taxpayers towards compliance is affected by the social groups, norms, and interactions, like any other form of behavior (Snavely 1990). The model also assumes that taxpayers are motivated to comply by the presence of government expenditure; if the government increases the provision of public goods and services, providing efficient in more accessible way commodities that are preferred citizens than tax compliance will increase (Levi 1988; Tilly 1992; Alm et al 1992; Moore 2004). Tax paid and the goods and services provided by the government are correlated, taxpayers are concerned about what they will get and benefit in the form of public goods and services from the government after making their tax payments (Fjeldstad and Semboja 2001; Moore 2004). If taxpayers in their circles view government as not willing to return back to the public, they influence each other not to comply and people comply believing that their peers are also complying whilst those who cheat understand that there are many of their peers who do the same.

\section{Methodology}

The survey research design was used, with the research aims in consideration, data was collected from primary sources and the SMEs operating in the Bulawayo provincewere considered asthesample of the study. A pre test was conducted to collect feedback about the research instruments. Both questionnaires and interviews were used to collect data. After a pilot test was conducted using 10 questionnaires on SMEs in the city of Bulawayo. A Postal questionnaire with closed ended questions, using an eight-point Likert scale was sent to 185 entities. Out of the 185 questionnaires issued, 150 were returned. The stratified random sampling technique was adopted to elicit information from SMEs operating the province. Ten key-informant interviews with accountants were conducted to collect qualitative data (with open-ended questions) from those who had responded to the questionnaires. The aim of the interviews was to gain more insights into the survey results and check the reliability of the quantitative data obtained through postal questionnaires. A model was developed to find the relationship between tax compliance and the determinants of tax compliance (Financial constraints, Tax audit, Tax education, Public funds abuse, and Tax rate) and the model was tested using regression analysis on SPSS version 22. Analysis of variance was used to check the strength of the relationship between dependents and independent variables. Tables were used for data presentation. Data collected from the interview was analyzed through summative content analysis and the quantitative data 
from questionnaires was analyzed using SPSS ver.22. The hypotheses were collapsed into two main categories as:

$\mathbf{H}_{0}$. There is no relationship between tax compliance and any of the determinants (Financial constraints, Tax audit, Tax education, Public funds abuse, and Tax rate).

$\mathbf{H}_{\mathbf{1}}$. There is a relationship between tax compliance and at least one of the determinants (Financial constraints, Tax audit, Tax education, Public funds abuse, and Tax rate).

Table 1: Tax Compliance and non compliance Studies Reviewed

\begin{tabular}{|c|c|c|c|c|c|}
\hline Author(s) & Year & Method & Sample Size & Country & Findings of the study \\
\hline $\begin{array}{l}\text { Mukhlis, } \\
\text { Utomo \& } \\
\text { Soesetyo }\end{array}$ & 2014 & $\begin{array}{l}\text { Descriptive } \\
\text { Method }\end{array}$ & $\begin{array}{l}61 \\
\text { respondents }\end{array}$ & Indonesia & $\begin{array}{l}\text { Taxpayers comply when there is } \\
\text { fairness and benefits that can be } \\
\text { received from complying. }\end{array}$ \\
\hline $\begin{array}{l}\text { Damayanti } \\
\text { et.al., }\end{array}$ & 2015 & $\begin{array}{l}\text { Descriptive } \\
\text { Method } \\
\text { regression } \\
\text { analysis }\end{array}$ & $\begin{array}{l}323 \\
\text { individual } \\
\text { taxpayers in } \\
\text { the Central } \\
\text { Java }\end{array}$ & Indonesia & $\begin{array}{l}\text { Tax compliance behavior is } \\
\text { influenced by the intention to } \\
\text { comply, while the intention to } \\
\text { comply is influenced by subjective } \\
\text { norms and by the perception of the } \\
\text { government. }\end{array}$ \\
\hline $\begin{array}{l}\text { Appah \& } \\
\text { Wosowei }\end{array}$ & 2016 & $\begin{array}{l}\text { Relevant } \\
\text { diagnostics } \\
\text { tests and } \\
\text { multiple } \\
\text { regression } \\
\text { models. }\end{array}$ & $\begin{array}{l}785 \\
\text { individual } \\
\text { taxpayers }\end{array}$ & Nigeria & $\begin{array}{l}\text { The findings of the study showed } \\
\text { that the behavior of taxpayers is } \\
\text { based on their financial condition, } \\
\text { risk preference, the nature of the } \\
\text { society in terms of the level of } \\
\text { governance. }\end{array}$ \\
\hline $\begin{array}{l}\text { Alasfour } \\
\text { et.al., }\end{array}$ & 2016 & $\begin{array}{l}\text { Descriptive \& } \\
\text { multivariate } \\
\text { tests }\end{array}$ & $\begin{array}{l}375 \\
\text { respondents }\end{array}$ & Jordan & $\begin{array}{l}\text { The study revealed that the extent } \\
\text { of the governmental corruption } \\
\text { and government expenditure has } \\
\text { an effect on tax compliance. High } \\
\text { tax rates and the taxation system's } \\
\text { being perceived as unjust, causes } \\
\text { non tax compliance whilst an } \\
\text { increase in tax audit and heavy } \\
\text { penalty rates reduces tax evasion. }\end{array}$ \\
\hline $\begin{array}{l}\text { Riahi- } \\
\text { Belkaoui }\end{array}$ & 2004 & $\begin{array}{l}\text { Multiple } \\
\text { regression }\end{array}$ & 30 countries & $\begin{array}{l}\text { World- } \\
\text { wide }\end{array}$ & $\begin{array}{l}\text { The findings showed that tax } \\
\text { compliance is positively related to } \\
\text { the level of economic freedom, and } \\
\text { the effectiveness of laws and } \\
\text { negatively related to the rate of } \\
\text { crime as a proxy for moral norms }\end{array}$ \\
\hline $\begin{array}{l}\text { Frey } \\
\text { Feld }\end{array}$ & 2002 & $\begin{array}{l}\text { Descriptive } \\
\text { statistics and } \\
\text { regression } \\
\text { analysis }\end{array}$ & $\begin{array}{l}23111 \\
\text { individual } \\
\text { taxpayers }\end{array}$ & $\begin{array}{l}\text { Switzerlan } \\
\mathrm{d}\end{array}$ & $\begin{array}{l}\text { Tax morale of the taxpayers is raised } \\
\text { when the tax (authority) officials } \\
\text { treat them with respect. }\end{array}$ \\
\hline $\begin{array}{l}\text { Zivanai } \\
\text { et.al, }\end{array}$ & 2016 & Survey & 30 SMEs & $\begin{array}{l}\text { Zimbabwe } \\
\text { (Bindura) }\end{array}$ & $\begin{array}{l}\text { Findings revealed that, lack of trust } \\
\text { in the tax authority and the fact that } \\
\text { fellow informal traders are evading } \\
\text { taxes encourages other taxpayers } \\
\text { not comply. }\end{array}$ \\
\hline Maseko & 2014 & $\begin{array}{l}\text { Descriptive } \\
\text { statistics and } \\
\text { correlation }\end{array}$ & $\begin{array}{l}163 \\
\text { respondents }\end{array}$ & $\begin{array}{l}\text { Zimbabwe } \\
\text { (Harare, } \\
\text { Chitungwi } \\
\text { za and } \\
\text { Bindura) }\end{array}$ & $\begin{array}{l}\text { The results indicated that high tax } \\
\text { rates, the perceptions of SME } \\
\text { operators about tax fairness, tax } \\
\text { service quality and government } \\
\text { spending priorities greatly affect } \\
\text { their tax compliance decisions. }\end{array}$ \\
\hline
\end{tabular}




\section{Journal of Economics and Behavioral Studies (ISSN: 2220-6140)}

Vol. 9, No. 4, pp. 242-250, August 2017

\section{Results and Discussion}

The regression equation was established as follows:

Table 2: Descriptive results

\begin{tabular}{lllll}
\hline & N & Mean & & Std. Deviation \\
& Statistic & Statistic & Std. Error & Statistic \\
\hline Compliance & 150 & 3.36 & .152 & 1.862 \\
Financial Constraints & 150 & 3.86 & .131 & 1.610 \\
Tax Audit & 150 & 3.57 & .154 & 1.884 \\
tax education & 150 & 3.17 & .102 & 1.252 \\
public funds abuse & 150 & 2.51 & .109 & 1.340 \\
Tax Rate & 150 & 3.61 & .089 & 1.092 \\
\hline
\end{tabular}

Table 3: Regression statistics

\begin{tabular}{llcll}
\hline Model & R & R Square & Adjusted R Square & Std. Error of the Estimate \\
\hline 1 & $0.900^{\mathrm{a}}$ & 0.809 & 0.802 & 0.827 \\
\hline
\end{tabular}

Table 4: ANOVA a

\begin{tabular}{lllllll}
\hline Model & & Sum of Squares & df & Mean Square & F & Sig. \\
\hline 1 & Regression & 417.961 & 5 & 83.592 & 122.084 & $.000^{\mathrm{b}}$ \\
& Residual & 98.599 & 144 & 0.685 & & \\
& Total & 519.56 & 149 & & & \\
\hline
\end{tabular}

Table 5: Coefficients a

\begin{tabular}{|c|c|c|c|c|c|}
\hline \multirow[t]{2}{*}{ Model } & \multicolumn{2}{|c|}{$\begin{array}{l}\text { Unstandardized } \\
\text { Coefficients }\end{array}$} & \multirow{2}{*}{$\begin{array}{l}\text { Standardized } \\
\text { Coefficients } \\
\text { Beta }\end{array}$} & \multirow[t]{2}{*}{$\mathbf{t}$} & \multirow[t]{2}{*}{ Sig. } \\
\hline & B & Std. Error & & & \\
\hline (Constant) & 2.277 & 0.475 & & 4.796 & .000 \\
\hline Financial Constraints & -0.24 & 0.052 & -0.208 & -4.63 & .000 \\
\hline Tax Audit & 0.754 & 0.045 & 0.762 & 16.636 & .000 \\
\hline Tax Education & 0.081 & 0.059 & 0.055 & 1.382 & 0.169 \\
\hline Public Funds Abuse & -0.121 & 0.057 & -0.087 & -2.122 & 0.036 \\
\hline Tax Rate & -0.176 & 0.67 & -0.103 & -2.631 & 0.009 \\
\hline
\end{tabular}

Table 6: Correlations

\begin{tabular}{lllllll}
\hline & Compliance & $\begin{array}{l}\text { Financial } \\
\text { Constraints }\end{array}$ & $\begin{array}{l}\text { Tax } \\
\text { Audit }\end{array}$ & $\begin{array}{l}\text { Tax } \\
\text { Education }\end{array}$ & $\begin{array}{c}\text { Public Funds } \\
\text { Abuse }\end{array}$ & $\begin{array}{c}\text { Tax } \\
\text { Rate }\end{array}$ \\
\hline $\begin{array}{l}\text { Pearson Correlation } \\
\text { Compliance }\end{array}$ & 1 & -0.621 & 0.876 & 0.249 & 0.021 & 0.001 \\
Financial Constraints & -0.621 & 1 & -0.558 & -0.028 & -0.197 & 0.037 \\
Tax Audit & 0.876 & -0.558 & 1 & 0.239 & 0.060 & 0.094 \\
Tax Education & 0.249 & -0.028 & 0.239 & 1 & -0.281 & 0.173 \\
Public Funds Abuse & 0.021 & -0.197 & 0.06 & -0.281 & 1 & -0.354 \\
Tax Rate & 0.001 & 0.037 & 0.094 & 0.173 & -0.354 & 1 \\
\hline
\end{tabular}

The average compliance rating was 3.36 whilst the average education rating was 3.17 and that of public funds abuse was at 2.51 as shown in table 2. The results of the regression analysis shown in table 3 above were used to test the relationship between tax compliance and financial constraints, tax audit, tax education, public 
funds abuse and tax rate among small to medium enterprises in Zimbabwe. The analysis shows that the adjusted R squared $=0.802 ; 80 \%$ of changes in tax compliance is explained by financial constraints, tax audit, tax education, public funds abuse and the tax rate. Correlation among predictor variables appears to be low and acceptable as shown in table 6 above. The model was run at $5 \%$ level of significance and the following results were obtained. The ANOVA summarized in table 4 reveals that $p$-value $=0.00$ which is less than 0.05 demonstrating a significant and valid model. The model reveals that tax compliance is inversely related to financial constraints; if financial constraint increase non-compliance, increase as shown by a coefficient of (0.24) and results are similar to the findings by Appah \& Wosowei, (2016). Tax audit has a strong positive relationship with tax compliance; with more tax audit there is an increase in tax compliance, these results are the same with the findings of Riahi-Belkaoui, (2004); Alasfour, et.al., (2016), and tax audit has the highest influence on compliance as is shown by a coefficient of (0.754). The A-S model also supports the results of the study; it states that if tax audit and follow-up strategies are poor, taxpayers will evade taxes and if penalties are not severe non-compliance will be high (Bătrâncea, 2012; Devos, 2014; Ali, et.al. 2013; Zivanai, et.al. 2016). These findings are in agreement with the results by Utaumire et al (2013) and Zivanai, et.al (2014) who noted that ZIMRA has weak follow-up and insufficient awareness campaigns.

Tax education has a positive insignificant relationship with tax compliance (coefficient $=0.081$ ), among all the variables it has the lowest influence. Public funds abuse has a negative relationship with to tax compliance as shown by a coefficient of -0.121 and (tax rate) -.0176; if public funds are abused there is increase in noncompliance, the results are consistent with results by Fjeldstad and Semboja (2001); Frey \& Feld , (2002); Moore (2004);Riahi-Belkaoui, (2004); Maseko, (2014); Mukhlis, Utomo \& Soesetyo, (2014); Dube (2014); Damayanti et.al., (2015); who stated that tax compliance is correlated with government expenditure on public goods and services and there is a strong negative relationship between the two. The tax rate is negatively related to tax compliance (coefficient= -. 0176); an increase in tax rate will reduce tax compliance, the results are correlative to the findings of Ojeka and Ojochogwu (2012); Alasfour, et.al, (2016) who agreed that high tax rates promote tax evasion among SMEs

\section{Conclusion}

The study examined the predictors of tax non-compliance among SMEs in Zimbabwe. Three main models on tax compliance were reviewed on literature, strong evidence of tax compliance determinants was provided. The study concluded that major leading factors in tax non-compliance of taxpayers are a lack of tax audit and poor follow-up strategies by the tax authority, high tax rates, financial constraints, public funds abuse by government and tax education. Taxpayers are aware of tax obligation and the possibility of being detected by tax authority is low though the penalties are heavy. ZIMRA should improve the tax administration system and reinforce the tax collection strategies and follow up on SMEs. Tax incentives like lowering the tax rates and tax reform will increase the revenue collection of taxes. Massive campaigns against evasion and avoidance of tax and intensive tax education should be embarked on. ZIMRA employees should also be well equipped for easy detection of tax evasion. Governments can consider developing a new tax system that suits SMEs which will lower compliance costs. Tax rates are perceived to be too high. The government should consider revising the tax policy or reducing tax rates as they promote tax evasion and failure among SMEs businesses. More support and increased tax incentives through tax support services should be offered to SMEs to cut their failure rate as they are the engine of economic growth.

\section{References}

African Forum and Network on Debt and Development (AFRODAD), (2011). What Has Tax Got To Do With Development: A critical look at Zimbabwe's Tax System.

Ali, M., Fjeldstad,O., HoemSjursen, I., (2013). Factors affecting tax compliant attitude in Africa: Evidence from Kenya, Tanzania, Uganda and South Africa.

Allingham, M.G., Sandmo, A. (1972). Income Tax Evasion: A Theoretical Analysis. Journal of Public Economics 1, 323-338.

Alm, J., G. H. McClelland \& W. D. Schulze (1992). Why do people pay taxes? Journal of Public Economics, 48, 21-38.

Andreoni, J., Erard, B., Feinstein, J.S., (1998). Tax Compliance. Journal of Economic Literature, 36(2), 818-860. 
Appah, E., Wosowei, E. C. (2016) Tax Compliance Intentions and the Behavior of the Individual Taxpayer: Evidence from Nigeria. Research Journal of Finance and Accounting www.iiste.org ISSN 2222-1697 (Paper) ISSN 2222-2847 (Online) 7(13), 20161.

Bătrâncea, L., Nichita, R., Bătrâncea, I., and Moldovan, B.A., (2012). Tax Compliance Models: From Economic To Behavioral Approaches. Transylvanian Review of Administrative Sciences, 36, 13-26.

Cobham, A. (2005). Taxation policy and development. Oxford: The Oxford Council on Good Governance.

Damayanti, T.H., Sutrisno, T., Subekti, I., \& Baridwan, Z. (2015)The Role of Taxpayer's Perception of the Government and Society to Improve Tax Compliance. Accounting and Finance Research, 4(1); ISSN 1927-5986 E-ISSN 1927-5994.

De Mello, L. (2008). Avoiding the Value Added Tax: Theory and Cross-Country Evidence", OECD Economics Department Working Papers, No. 604, OECD Publishing, and Paris.

Devos, K. (2014). Factors Influencing Individual Taxpayer Compliance Behavior, Springer Netherlands, eBook ISBN: 978-94-007-7476-6 http://www.springer.com/gp/book/9789400774759.

Dube, G. (2014). Informal sector tax administration in Zimbabwe. University of KwaZulu-Natal, South Africa.

Gahramanov, E. (2009). The Theoretical Analysis of Income Tax Evasion Revisited. Economic Issues, 14(1) $2009,35$.

Erard, B., Feinstein, J. S., (1994). Honesty and Evasion in the Tax Compliance Game. Rand Journal of Economics, 25(1), 1-20.

Alasfour, F., Samy, M., Bampton, R. (2016). The Determinants of Tax Morale and Tax Compliance: Evidence from Jordan, in John Hasseldine (ed.) Advances in Taxation, 23, 125-171.

Fauvelle-Aymar, C. 1999. The political and tax capacity of government in developing countries. Kyklos, 52, 391-413.

Fischer, C.M., Wartick, M. and Mark, M. (1992). Detection Probability and Taxpayer Compliance: A Review of the Literature. Journal of Accounting Literature, 11, 1-46.

Fjeldstad, O.-H. \& Semboja, J. (2001). Why people pay taxes: The case of the development levy in Tanzania. World Development, 29, 2059-2074.

Frey, B. \& Feld, L., (2002). Deterrence and morale in taxation: An empirical analysis. Working paper, No. 760.

Gordon, J.P.F. (1989). Individual Morality and Reputation Costs as Deterrence to Tax Evasion. European Economic Review, 33(4), 797-805.

http://www.zimra.co.zw/index.php?option=com_content\&view=article\&id=2285:tax-obligations-andconcessions-for-smes-\&catid=21:did-you-know\&Itemid=91

http://www.zimra.co.zw/index.php?option=com_content\&view=article\&id=1965: special-initial-allowancefor-small-to-medium-enterprise-smes\&catid=21:did-you-know\&

Keen, M. (2012). Taxation and Development-Again. New York: International Monetary Fund, Working Paper $/ 12 / 220$.

Kirchler, E. (2007). The Economic Psychology of Tax Behavior. Cambridge University Press, Cambridge.

Kirchler, E, Hoelzl, E \& Wahl, I. (2008). Enforced Versus Voluntary tax compliance: The 'slippery slope' framework. Journal of Economic Psychology .01/2008.

Levi, M. (1988). Of rule and revenue, Berkeley: University of California Press.

Maseko, N. (2014). Determinants of Tax Compliance by Small and Medium Enterprises in Zimbabwe. Journal of Economics and International Business Research (JEIBR), 2(3), 48-57.

Moore, M. (2004). Revenues, state formation, and the quality of governance in developing countries. International Political Science Review, 25, 297-319.

Mukhlis, I., Utomo, S.H., Soesety, Y. (2014). Increasing Tax Compliance Through Strengthening Capacity Of Education Sector For Export Oriented SMEs Handicraft Field In East Java Indonesia. European Scientific Journal, 10(7) ISSN: 1857 - 7881 (Print) e - ISSN 1857- 7431, 170

Musarirambi, C. (2013). An investigation into factors associated with tax evasion in the Zimbabwe informal sector: A survey of MbareMagaba informal traders.

Odd-Helge, F., \& Rakner, L. (2009). The importance of taxes for development. Bergen, Norway: Chr. Michelsen Institute.

Ojeka, A. \& Ojochugwu W, A. (2012). Factors that affect tax compliance among SMEs in North Central Nigeria. International Journal of Business and Management, 7, 12.

Riahi-Belkaoui, A. (2004). Relationship between Tax Compliance Internationally and Selected Determinants of Tax Morale. Available at SSRN: https://ssrn.com/abstract $=484022$ or http://dx.doi.org/10.2139/ssrn.484022. 
Snavely, K. (1990). Governmental policies to reduce tax evasion: coerced behavior versus services and values development. Policy Sciences, 23, 57-72.

Tapera, M. (2010). Tax kit for business and economics, 7th edition, Harare.

Tapera, M. (2013). Taxation principles in Zimbabwe. (ISBN 9780797462953).

Tayler, T. R. (2006). Psychological perspectives on legitimacy and legitimation. Annual Review of Psychology, $57,375-400$.

Tilly, C. (1992). Coercion, capital and European states: AD 990-1992, Malden, Massachusetts: Blackwell Publishers Inc.

Utaumire, B., Mashiri, E., \& Mazhindu, K. (2013). Effectiveness of presumptive tax system in Zimbabwe: Case of ZIMRA Region one. Research Journal of Finance and Accounting, 4(7), 114-120.

Woro, D., Sutrisno T, Imam, S., \& Zaki B. (2015). The Role of Taxpayer's Perception of the Government and Society to Improve Tax Compliance. Accounting and Finance Research, 4(1), 180-184.

Yitzhaki, S. (1974). Income Tax Evasion: A Theoretical Analysis. Journal of Public Economics, 3(2), 201-202.

Zivanai, O., Chari F., Nyakurimwa, C., (2016). Tax Compliance Challenges in Fulfilling Tax Obligations among SMEs in Zimbabwe: A Survey of SMEs in Bindura.

Zivanai, O., Manyani, O., Hove, N., Chiriseri, L., Mudzura, M. (2014). The Effectiveness of Presumptive Tax and Its Impact on Profitability of SMEs in Zimbabwe. Case Of Commuter Transport Operators In Bindura. 